\title{
Hubungan Asupan Bahan Makanan Sumber Vitamin D Dan Vitamin C Terhadap Penurunan Glukosa Darah Pada Responden Terindikasi Diabetes Mellitus Tipe II
}

\section{Relationship Of Vitamin D And Vitamin C Food Intakes To Decrease Blood Glucose In Indicated Diabetes Mellitus Tipe II Respondents}

\author{
Rizki Nurmalya, Kardina ${ }^{1 *}$, Farah Nuriannisa ${ }^{2}$, Ary Andini ${ }^{3}$, Anita $^{4}$ \\ ${ }^{1,2}$ Program Studi S1 Gizi, Fakultas Kesehatan, Universitas Nahdlatul Ulama Surabaya \\ ${ }^{3,4}$ Program Studi D-IV Analis Kesehatan, Fakultas Kesehatan, Universitas Nahdlatul Ulama Surabaya \\ Jalan Raya Jemursari No. 57 Surabaya \\ *Corresponding author \\ Email: rizki_kardina@unusa.ac.id
}

Keyword :

Diabetes Mellitus

Glucose,

Vitamin D,

Vitamin $C$,

\begin{abstract}
A b stract
Background: Diabetes Mellitus type 2 is a disease caused by decreased insulin secretion and is characterized by an increase in blood glucose levels (hyperglycemia). Vitamin D has a role in insulin secretion, insulin metabolism by accelerating the conversion of proinsulin to insulin and increasing insulin sensitivity. Vitamin $C$ is a micronutrient that has an important role in human plasma as an antioxidant. Vitamin $C$ is water soluble and can fight free radicals. The function of Vitamin $C$ is as an electron donor or electron reducing agent so that it can act as an antioxidant. The aim was to determine the relationship between the intake of food sources of vitamin $D$ and vitamin $C$ on the decrease in blood glucose in respondents who indicated type II Diabetes Mellitus. The research method in this study is experimental with a cross-sectional approach using respondents in the area of Kutisai Village, Surabaya. In this study using 2 groups, namely the treatment group and the control group. The sampling technique used was incidental sampling with a total of 20 respondents, which were divided into 2 groups. Each group 10 respondents in the control group and 10 respondents in the treatment group. Samples were collected by taking blood on day 1 and day 7, FFQ - SQ interviews. The results showed that the two groups had the same results, there was no relationship between the intake of food sources of vitamin $D$ and vitamin $C$ which was identified as diabetes mellitus in the control and treatment groups. Conclusion There is no relationship between the intake of vitamin $D$ and vitamin $C$ on the decrease in blood glucose levels in respondents who are indicated by type II Diabetes Mellitus.
\end{abstract}

\section{Kata kunci :}

Diabetes Mellitus

Glukosa,

Vitamin $C$,

Vitamin D,

\begin{abstract}
A B S T R A K
Latar belakang: Diabetes Mellitus tipe 2 merupakan penyakit yang disebabkan oleh penurunan sekresi insulin dan ditandai dengan peningkatan kadar glukosa darah (hiperglikemia). Vitamin D memiliki peranan terhadap sekresi insulin, metabolisme insulin dengan mempercepat perubahan proinsulin menjadi insulin dan meningkatkan sensitifitas insulin. Vitamin $\mathrm{C}$ adalah golongan mikronutrien yang memiliki peran penting dalam plasma manusia sebagai antioksidan. Vitamin $\mathrm{C}$ mempunyai sifat larut air dan mampu melawan radikal bebas. Fungsi Vitamin $\mathrm{C}$ adalah sebagai donor elektron atau agen pereduksi elektron sehingga mampu berperan sebagai antioksidan. Tujuan ingin mengetahui hubungan asupan bahan makanan sumber vitamin D dan vitamin $\mathrm{C}$ terhadap penurunan glukosa darah pada responden yang terindikasi Diabetes Mellitus tipe II. Metode penelitian pada penelitian ini adalah eksperimental dengan pendekatan crosssectional dengan menggunakan responden di wilayah kelurahan Kutisai, Surabaya. Dalam penelitian ini menggunakan 2 kelompok yaitu kelompok perlakuan dan kelompok kontrol. Teknik pengambilan sampel yang digunakan adalah incidental sampling dengan jumlah 20 responden, yang terbagi menjadi 2 kelompok. Setiap kelompok 10 responden
\end{abstract}


kelompok kontrol dan 10 responden kelompok perlakuan. Pengumpulan sampel dengan dilakukan dengan pengambilan darah hari 1 dan hari 7, wawancara FFQ-SQ. Hasil penelitian menunjukkan kedua kelompok baik kelompok kontrol dan perlakuan sama sama memiliki hasil tidak terdapat hubungan asupan bahan makanan sumber vitamin $\mathrm{D}$ dan vitamin $\mathrm{C}$ pada responden yang terindikasi diabetes mellitus tipe II . Kesimpulan Tidak ada hubungan antara asupan bahan makanan sumber vitamin D dan vitamin $\mathrm{C}$ terhadap penurunan kadar glukosa darah pada responden yang terindikasi Diabetes Mellitus tipe II.

\section{LATAR BELAKANG}

Diabetes mellitus (DM) tipe 2 merupakan penyakit yang dapat disebabkan oleh penurunan sekresi insulin dan ditandai dengan peningkatan kadar glukosa darah (hiperglikemia). ${ }^{1} \quad$ Hiperglikemia dapat disebabkan oleh adanya kelainan sekresi insulin. Penyakit DM Tipe 2 memiliki perkembangan yang dapat menimbulkan stres oksidatif yang ditandai oleh ketidakseimbangan antara oksidan dan antioksidan dalam tubuh. Kondisi stres dapat meningkatkan stres oksidatif yang mengakibatkan terjadinya perubahan aktivitas antioksidan endogen dan juga meningkatkan kerusakan biomolekul secara oksidatif. $^{2}$

Menurut International Diabetes Federation (IDF), 2009 Indonesia diprediksi mengalami peningkatan prevalensi diabetes melitus hingga 2 kali lipat pada tahun 2030. Sedangkan menurut data Riset Kesehatan Dasar (Riskesdas) 2013 dan 2018 menunjukkan bahwa penderita diabetes melitus di Indonesia meningkat $1,3 \%$ dari tahun 2013 sebesar $2,1 \%$ menjadi $3,4 \%$ di tahun 2018. . $^{3,4}$

Diabetes mellitus (DM) ditandai dengan tingginya kadar gula dalam darah atau yang biasa disebut dengan hiperglikemia. Menurunnya daya kerja insulin pada pankreas akan menyebabkan glukosa kurang diserap baik oleh sel-sel dalam tubuh. Glukosa teresebut hanya akan berakumulasi dalam darah yang kemudian akan beredar keseluruh tubuh sehingga mengakibatkan tingginya kadar gula darah pada seseorang. ${ }^{5}$ Diabetes melitus bisa terjadi akibat defisiensi vitamin D. Pada penderita diabetes melitus tipe 2, injeksi insulin bisa dilakukan namun tidak dapat bekerja secara optimal untuk membantu selsel tubuh menyerap glukosa. ${ }^{6}$

Vitamin D sering dikenal dengan vitamin matahari karena vitamin $\mathrm{D}$ dapat dibentuk tubuh dengan bantuan sinar matahari. Bila tubuh mendapat cukup sinar matahari, maka konsumsi vitamin D melalui asupan makanan tidak dibutuhkan. Tingginya defisiensi vitamin D dalam tubuh seseorang dikaitkan dengan paparan sinar matahari yang rendah. ${ }^{7}$

Menurut Kathore (2015) dalam penelitiannya tentang pengaruh vitamin $\mathrm{C}$ terhadap kadar glukosa darah puasa dan profil lipid pada pasien diabetes melitus Tipe 2, dilakukan pada 50 pasien DM tipe 2 yang memiliki kriteria usia 40 hingga 80 tahun dengan tingkat kadar glukosa darah kurang dari $250 \mathrm{mg} / \mathrm{dl}$. Perlakuan dilakukan dengan pemberian suplementasi Vitamin C yang memiliki dosis $1000 \mathrm{mg} /$ hari selama 12 minggu. Penelitian tersebut menunjukan hasil yang signifikan dengan nilai $\mathrm{P}<0,05$ yang menunjukan bahwa suplementasi 1000 mg Vitamin $C$ setiap hari dalam 12 minggu pada pasien diabetes melitus tipe 2 menyebabkan penurunan kadar glukosa darah puasa, kadar kolesterol serum, kadar trigliserida dan VLDL, serta meningkatnya kadar kolesterol lipoprotein densitas tinggi. ${ }^{8}$ Tujuan penelitian ini adalah untuk mengetahui hubungan asupan bahan makanan sumber vitamin D dan vitamin C terhadap penurunan kadar glukosa darah pada responden yang terindikasi Diabetes mellitus tipe 2 .

\section{METODE}

Penelitian ini merupakan penelitian Eksperimental dengan pendekatan crossecsional dengan menggunakan 
responden di wilyah kelurahan Kutisari, Surabaya. Dalam penelitian ini menggunakan 2 kelompok perlakuan yaitu responden yang tanpa perlakuan terapi berjemur (DMTJ) dan responden dengan terapi berjemur (DMJ). Kriteria inklusi dari penelitian ini adalah berjenis kelamin lakilaki atau perempuan, berusia $>40$ tahun, terindikasi diabetes mellitus tipe 2. Kriteria eksklusi pada penelitian ini adalah mengkonsumsi obat antidiabetik, memakai tabir surya dalam keseharian, alergi terhadap paparan sinar matahari. Teknik pengambilan sampel yang digunakan yaitu incidental sampling dengan menentukan sampel berdasarkan kebetulan/incidental dengan pertimbangan tertentu sehingga layak dijadikan sampel dengan pertimbangan sesuai syarat inklusi dan ekslusi sehingga layak untuk dijadikan sebagai sampel penelitian. Masing-masing kelompok 10 kelompok kontrol dan 10 kelompok perlakuan. Keterangan laik etik no. 087/EC/KEPK/UNUSA/2020

\section{Lokasi dan Waktu Penelitian}

Penelitian ini dilakukan di rumah rumah penduduk setempat setelah mendapatkan ijin lurah dan RT di wilayah kerja Kelurahan Kutisari Surabaya dan pengambilan sampel darah kapiler responden yang terindikasi diabetes mellitus tipe 2 , responden yang terindikasi diabetes mellitus memiliki kadar glukosa darah dua jam setelah makan sebesar $\geq 200 \mathrm{mg} / \mathrm{dl}$ dan wawancara digunakan untuk mengetahui kebiasaan asupan bahan makanan sumber vitamin $\mathrm{D}$ dan vitamin $\mathrm{C}$ dengan menggunakan form SQ-FFQ.

\section{Instrumen}

Dalam penelitian ini menggunakan beberapa alat untuk pemeriksaan kadar glukosa darah yang menggunakan sampel darah kapiler pada jari manis responden, sedangkan waktu pengukuran kadar glukosa darah dilakukan dua jam setelah makan. Pengukuran kadar glukosa darah menggunakan metode Point Care of Testing (POCT) dengan merk EasyTouch, lancet, kapas, alkohol, autoclik merk Sella, strip tes glukosa darah merk EasyTouch, form $S Q$ $F F Q$ digunakan untuk mengetahui kebiasaan asupan bahan makanan sumber vitamin D dan vitamin $\mathrm{C}$.

\section{Analisa data}

Analisa data penelitian ini menggunakan uji statistik dengan menggunakan uji hubungan Correlation test dengan uji person secara statistik utuk mengetahui hubungan asupan bahan makanan sumber vitamin D dan vitamin C terhadap penurunan kadar glukosa darah pada responden yang terindikasi Diabetes meliitus tipe II dengan bantuan SPSS (Satistical Package For Social Science).

\section{HASIL PENELITIAN}

Hasil Penelitian meliputi karakteristik responden berdasarkan usia, jenis kelamin, status gizi pada kelompok perlakuan dan kelompok kontrol yang terindikasi Diabetes Mellitus tipe 2.

\section{Karakteristik Responden berdasarkan Jenis Kelamin}

Penentuan responden berdasarkan jenis kelamin pada penelitian ini dipilih secara acak. Sementara pembagian responden berdasarkan kelompok kontrol dan perlakuan sesuai dengan kriterian inklusi.

Tabel 1. Distribusi Responden berdasarkan Jenis Kelamin

\begin{tabular}{|c|c|c|c|c|}
\hline \multirow[t]{2}{*}{ JK } & \multicolumn{2}{|c|}{ Kelompok } & \multirow[t]{2}{*}{$\mathrm{N}$} & \multirow[t]{2}{*}{$\%$} \\
\hline & DMJ & DMTJ & & \\
\hline $\mathrm{P}$ & 2 & 8 & 10 & 50 \\
\hline $\mathrm{L}$ & 8 & 2 & 10 & 50 \\
\hline Total & 10 & 10 & 20 & 100 \\
\hline
\end{tabular}

Ket. : JK: Jenis Kelamin, P: perempuan, L: laki-laki, N: frekuensi, \% :presentase, DMJ: diabetes melitus berjemur, DMTJ: Diabetes melitus tanpa berjemur 
Berdasarkan data yang disajikan pada tabel 1 didapatkan karakteritik responden berdasarkan jenis kelamin jika setengahnya responden pada penelitian ini adalah perempuan (50\%) dan laki $(50 \%)$.

Tabel 2. Distribusi Responden berdasarkan Usia

\begin{tabular}{ccccc}
\hline \multirow{2}{*}{ Usia } & \multicolumn{2}{c}{ Kelompok } & $\mathrm{N}$ & $\%$ \\
\cline { 2 - 3 } & DMJ & DMTJ & & \\
\hline$<45$ & 1 & 2 & 3 & 15 \\
$45-59$ & 1 & 2 & 3 & 15 \\
$60-74$ & 3 & 6 & 9 & 45 \\
$75-90$ & 1 & 0 & 1 & 5 \\
Total & 10 & 10 & 20 & 100 \\
\hline
\end{tabular}

Ket. : N: frekuensi, \% :presentase, DMJ: diabetes melitus berjemur, DMTJ: Diabetes melitus tanpa berjemur

Berdasarkan data yang telah disajikan pada tabel 2 didapatkan karakteritik responden berdasarkan usia jika sebagian besar responden adalah dengan rentang usia 60 - 74 tahun (45\%).

\section{Karakteristik Responden Berdasarkan Status Gizi}

Menurut Kristiandi (2015), status gizi merupakan pengukuran untuk menentukan status nutrisi seseorang yang dilihat berdasarkan tinggi badan dan berat badan.

Tabel 3. Distribusi Responden berdasarkan Status Gizi

\begin{tabular}{|c|c|c|c|c|}
\hline \multirow{2}{*}{$\begin{array}{c}\text { Status } \\
\text { Gizi }\end{array}$} & \multicolumn{2}{|c|}{ Kelompok } & \multirow[t]{2}{*}{$\mathrm{N}$} & \multirow[t]{2}{*}{$\%$} \\
\hline & DMJ & DMTJ & & \\
\hline $\begin{array}{l}\text { Kurus } \\
<18,5\end{array}$ & 4 & 2 & 6 & $30 \%$ \\
\hline $\begin{array}{l}\text { Normal } \\
18,5-22,9\end{array}$ & 5 & 7 & 12 & $60 \%$ \\
\hline $\begin{array}{l}\text { Lebih } \\
23->30\end{array}$ & 1 & 1 & 2 & $10 \%$ \\
\hline Total & 10 & 10 & 20 & $100 \%$ \\
\hline
\end{tabular}

Berdasarkan tabel 3 didapatkan bahwa status gizi responden baik kelompok kontrol maupun kelompok perlakuan memiliki status gizi normal (60\%).

\section{Karakteristik Responden Berdasarkan Kadar Glukosa Darah}

Pemeriksaan kadar glukosa darah pada responden sebanyak dua kali yaitu hari pertama dan hari ke tujuh, kemudian digunakan untuk penurunan kadar glukosa darah

Tabel 4. Distribusi Kadar Glukosa Darah pada kelompok Kontrol yang Terindentifikasi Diabetes Mellitus Tipe II

\begin{tabular}{cccc}
\hline \multirow{2}{*}{$\begin{array}{l}\text { Respon } \\
\text { den }\end{array}$} & \multicolumn{3}{c}{ Hasil kadar glukosa darah (mg/dl) } \\
\cline { 2 - 4 } & $\begin{array}{c}\text { Hari } \\
\text { ke-1 }\end{array}$ & $\begin{array}{c}\text { Hari } \\
\text { ke-7 }\end{array}$ & $\begin{array}{c}\text { Penurunan } \\
\text { Glukosa darah }\end{array}$ \\
\hline 1 & 311 & 376 & 65 \\
2 & 361 & 505 & 144 \\
3 & 299 & 382 & 83 \\
4 & 209 & 324 & 115 \\
5 & 280 & 368 & 88 \\
6 & 470 & 339 & -131 \\
7 & 241 & 263 & 22 \\
8 & 323 & 346 & 23 \\
9 & 240 & 462 & 222 \\
10 & 257 & 366 & 109 \\
\end{tabular}

Berdasarkan dari tabel 4 didapatkan rata rata seluruh responden yang teridentifikasi diabetes mellitus tipe II terdapat penurunan kadar glukosa darah pada kelompok kontrol (DMTJ)

Tabel 5. Distribusi Kadar Glukosa Darah pada kelompok Perlakuan yang Terindentifikasi Diabetes Mellitus Tipe II

\begin{tabular}{cccc}
\hline Responden & \multicolumn{3}{c}{ Hasil SQ-FFQ (mg/dl) } \\
\cline { 2 - 4 } & $\begin{array}{c}\text { Vitamin } \\
\text { D }\end{array}$ & $\begin{array}{c}\text { Vitamin } \\
\text { C }\end{array}$ & $\begin{array}{c}\text { Penurunan } \\
\text { Glukosa } \\
\text { darah }\end{array}$ \\
\hline 1 & 202 & 109 & -93 \\
2 & 365 & 195 & -170 \\
3 & 361 & 213 & -148 \\
4 & 202 & 114 & -88 \\
5 & 367 & 260 & -107 \\
6 & 278 & 168 & -110 \\
7 & 273 & 190 & -83 \\
8 & 451 & 366 & -85 \\
9 & 201 & 180 & -21 \\
10 & 461 & 314 & -147 \\
\hline
\end{tabular}

Berdasarkan pada tabel 5 didapatkan rata rata seluruh responden yang terindentifikasi diabetes mellitus tipe II pada kelompok 
Perlakuan mengalami penurunan kadar glukosa darah pada kelompok perlakuan (DMTJ)

Tabel 6. Distribusi Bahan makanan sumber vitamin D dan vitamin C

\begin{tabular}{ccc}
\hline Responden & \multicolumn{2}{c}{ Hasil Wawancara } \\
& Menggunakan SQ-FFQ (mg) \\
\cline { 2 - 3 } & Vitamin D & Vitamin C \\
\hline 1 & 56,3 & 595,3 \\
2 & 52,3 & 595 \\
3 & 67,8 & 550,5 \\
4 & 57,8 & 603 \\
5 & 56,3 & 613,5 \\
6 & 67,3 & 549 \\
7 & 72,8 & 4423 \\
8 & 57,8 & 633,5 \\
9 & 71,8 & 618,5 \\
10 & 68,3 & 596 \\
\hline
\end{tabular}

Berdasarkan tabel 6 didapatkan bahwa rata rata konsumsi asupan bahan makanan yang mengandung vitamin $\mathrm{D}$ dan vitamin C pada kelompok kontrol (DJNM) telah memenuhi kebutuhan responden.

Tabel 7. Distribusi Bahan makanan sumber vitamin $\mathrm{D}$ dan vitamin $\mathrm{C}$

\begin{tabular}{ccc}
\hline Responden & \multicolumn{2}{c}{ Hasil Wawancara } \\
& Menggunakan SQ-FFQ (mg) \\
\cline { 2 - 3 } & Vitamin D & Vitamin C \\
\hline 1 & 58,3 & 1031,6 \\
2 & 31,5 & 961 \\
3 & 65,8 & 1070,1 \\
4 & 64,8 & 1012,1 \\
5 & 51,3 & 1387,2 \\
6 & 43,6 & 1387,2 \\
7 & 30,5 & 960,9 \\
8 & 52,3 & 1098 \\
9 & 50,3 & 1096,2 \\
10 & 32,4 & 1696,7 \\
\hline
\end{tabular}

Berdasarkan tabel 7 didapatkan bahwa rata rata konsumsi asupan bahan makanan yang mengandung vitamin $\mathrm{D}$ dan vitamin $\mathrm{C}$ pada kelompok perlakuan telah memenuhi kebutuhan responden.

\section{Hubungan Vitamin D dan Vitamin C Terhadap Penurunan Glukosa}

Tabel 4. Hasil Uji Hubungan Asupan Bahan Makanan Vitamin D dan Vitamin C dengan Penuruna Glukosa darah Pada
Responden yang Terindikasi Diabetes Mellitus Tipe II

\begin{tabular}{cccccc}
\hline Variabel & \multirow{2}{*}{$\begin{array}{c}\text { Variabel } \\
\text { Dependen }\end{array}$} & \multicolumn{2}{c}{ DMJ } & \multicolumn{2}{c}{ DMTJ } \\
\cline { 3 - 6 } & den & $\mathrm{r}$ & $\mathrm{P}$ & $\mathrm{r}$ & $\mathrm{p}$ \\
\hline $\begin{array}{c}\text { Penurun } \\
\text { an kadar }\end{array}$ & Vit C & -.242 & .500 & -.186 & .607 \\
$\begin{array}{c}\text { Glukosa } \\
\text { Darah }\end{array}$ & & & & & \\
& Vit D & .259 & .469 & -.104 & .775 \\
\hline
\end{tabular}

Berdasarkan hasil uji hubungan dengan menggunakan uji person nilai $\mathrm{p}-$ value < 0,05 dari Vitamin $C$ sebesar 0,500 dan vitamin $\mathrm{D}$ sebesar 0,469 untuk kelompok berjemur dan $\mathrm{p}$-value $<0,05$ dari vitamin C 0,607 dan vitamin $D$ sebesar 0,775 yang menyatakan tidak ada hubungan antara asupan bahan makanan vitamin $\mathrm{D}$ dan vitamin $\mathrm{C}$ dengan penurunan kadar glukosa darah dengan Terapi berjemur yang dilakukan oleh responden yang terindikasi diabetes mellitus tipe II setiap pukul 07.00 pagi dengan lama berjemur yaitu 10 menit, dan yang terpapar sinar matahari hanya wajah dan kedua lengan.

\section{PEMBAHASAN}

Berdasarkan data yang disajikan pada tabel 1 didapatkan karakteritik responden berdasarkan jenis kelamin jika sebagian besar responden pada penelitian ini adalah perempuan (50\%). Perempuan ini memiliki resiko yang lebih besar untuk menderita penyakit Diabetes Mellitus dibandingkan laki laki. Hal ini sejalan dengan penelitian Lubis (2012) yang menunjukkan bahwa penderita DM tipe 2 lebih banyak terjadi pada perempuan. ${ }^{9}$

Berdasarkan data yang telah disajikan pada tabel 2 didapatkan karakteritik responden berdasarkan usia jika sebagian besar responden adalah dengan rentang usia 60 - 74 tahun $(45 \%)$. Dimana resiko diabetes mellitus akan terjadi pada usia diatas 40 tahun yang disebabkan oleh pola makan, aktivitas, dan konsumsi obat. Hal ini sejalan dengan penelitian Sunjaya (2009) peningkatan 
resiko diabetes mellitus berdasarkan rentang usia lebih dari 40 disebabkan karena terjadinya peningkatan intoleransi laktosa yaitu adanya proses penuan yang dapat menyebabkan berkurangnya kemampuan sel beta pankreas dalam memproduksi insulin didalam tubuh. ${ }^{10}$

Berdasarkan tabel 3 didapatkan bahwa status gizi responden baik kelompok kontrol maupun kelompok perlakuan memiliki status gizi normal $(60 \%)$. Status gizi salah satunya dipengaruhi oleh tingkat konsumsi makan. Pengaturan diet pada penderita DM harus diatur sesuai dengan jumlah asupan baik kalori, karbohidrat setiap harinya. Penyesuaian jumlah kalori, karbohidrat, lemak, protein dan serta dalam pola makan harus mempertimbangkan dan mempertahankan tingkat glukosa darah dan berat badan yang akan mempengaruhi statu gizi seseorang. ${ }^{11}$

Hal ini sejalan dengan penelitian yang dilakukan oleh Rochmah (2017) tidak terdapat hubungan signifikan asupan vitamin D dengan kadar glukosa darah puasa, dikarenakan responden memiliki asupan vitamin D dan asupan kalsium dengan kategori kurang. ${ }^{12}$ Pada responden penelitian ini rata rata memiliki usia yang $>55$ tahun yang telahmengalami menoupause dapat menyebabkan penurunan kadar vitamin $\mathrm{D}$ dalam tubuh. ${ }^{12}$ Hal ini dikarenakan asupan vitamin D tidak langsung mempengaruhi kadar glukosa darah, melainkan serum vitamin D yang mempengaruhi kadar glukosa darah terlebih dahulu yang mana serum vitamin D dapat meningkatkan sensitivitas dan sekresi insulin dalam tubuh. ${ }^{13}$ Meskipun dalam penelitian ini asupan vitamin D menunjukkan tidak terdapat hubungan yang signifikan dengan penurunan kadar glukosa darah, tetapi semakin rendah konsumsi asupan vitan D maka kadar glukosa darah semakin tinggi dengan nilai $\mathrm{r}$ (-.104). Sejalan dengan penelitian kohort bahwa subjek yang mengkonsumsi vitamin D >500IU/hari dapat menurunkan resiko diabets melittus sebesar $13 \%$ dibandingkan dengan subjek yang hanya mengkonsumsi vitamin D <200 IU/hari. ${ }^{13}$

Pada penelitian ini menyatakan bahwa asupan bahan makanan sumber vitamin $\mathrm{C}$ tidak berhubungan dengan kadar glukosa darah pada penderita yang terindikasi DM dengan terapi berjemur dan tidak berjemur. Hal ini sejalan dengan penelitian Indiry (2020) yang menyatakan kadar glukosa darah puasa tidak hanya mempengaruhi oleh asupan vitamin $\mathrm{C}$ tetapi juga dipengaruhi oleh konsumsi obat oral anti diabetes. Penelitian ini tidak melakukan kepatuhan dalam mengkonsumsi jenis obat yang akan mempengaruhi vitamin $\mathrm{C}$ dalam tubuh, karena kadar vitamin c bukan yang utama dalam proses pengendalian kadar glukosa dalam tubuh. Peran vitamin $\mathrm{C}$ salah satunya adalah dapat memperbaiki sel beta pankreas yang dapat menyebabkan resistensi insulin. Faktor yang mempengaruhi konsumsi asupan vitamin $\mathrm{C}$ dengan kadar glukosa darah adalah suhu yang tinggi selama proses pemasakan serta paparan sinar matahari. Adapun faktor lain yang mempengaruhi kadar glukosa darah dikarenakan sebagian besar responden penelitian ini adalah perempuan. Perempuan memiliki resiko lebih besar mengalami diabets meleitus tiipe 2 dibandingkan dengan laki laki yang disebabkan oleh penurunan hormon etrogen yang dapat menyebabkan resisten insulin

\section{Kesimpulan}

Tidak ada hubungan antara asupan bahan makanan sumber vitamin $\mathrm{D}$ dan vitamin $\mathrm{C}$ terhadap penurunan kadar glukosa darah pada responden yang terindikasi Diabetes Mellitus tipe II.

\section{Saran}

Perlu mengembangkan penelitian dengan menambahkan faktor-faktor lain yang dapat mempengaruhi kadar glukosa darah dan sumber bahan makanan dapat menurunkan kadar glukosa darah 


\section{DAFTAR PUSTAKA}

1. American Diabetes Association, Standart of medical care in diabetes. Diabetes Care. 2013.

2. W. Widowati, "Potensi Antioksidan Sebagai Antidiabetes," JMH, vol. 7, no. 2, p. 149640, 2008.

3. Balitbang Kemenkes RI, "Riset Kesehatan Dasar." 2013.

4. Balitbang Kemenkes RI, "Riset Kesehatan Dasar." 2018.

5. Ganong, Buku Ajar Fisiologis Kedokteran. EGC, 2003.

6. Micic, D and Cvijovic, G, Abdominal Obesity and Type 2 Diabetes. 2008.

7. Parker, J. et.al., "Levels of vitamin D and cardiometabolic disorders: systematic review and meta-analysis," Maturitas, p. 65(3): p. 225-236, 2010.

8. Kathore, V.R and Bansode, D.G, "The effect of vitamin $\mathrm{C}$ on fasting blood glucose level and lipid profile in type2 diabetes mellitus patients," . International Journal of Recent Trends in Science and Technology, $\mathrm{p}$. 16(3): 585-590, 2015.
9. Lubis, J. P, "Perilaku Penderita Diabetes Melitus Rawat Jalan di RSUD Rantauprapat Kabupaten Labuhanbatu Dalam Pengaturan Pola Makan," 2012.

10. Sunjaya and I Nyoman, "Pola Konsumsi Makanan Tradisional Bali Sebagai Faktor Risiko Diabetes Mellitus Tipe 2 di Tabanan," Jurnal Skala Husada, vol. 6 No. 1, pp. 75-81, 2009.

11. Prince $\mathrm{S}$ and Wilson LM, Konsep Klinis Proses-Proses Penyakit. 2005.

12. N. Rochmah, E. Probosari, and F. F. Dieny, "Hubungan Asupan Vitamin D dan Kalsium dengan Kadar Glukosa Darah Puasa Wanita Obesitas Usia 45 55 Tahun," PhD Thesis, Diponegoro University, 2017.

13. Pittas $G$ and Dawson-Hughes B, "Vitamin D and Diabetes," J Steroid Biochem Mol Biol, pp. 425-429, 2010.

14. Indry Wulansari, "Hubungan Asupan Vitamin C dengan Kadar Glukosa Darah Pada Pasien Diabetes Mellitus Tipe II Di Puskesmas Tawangsari Sukoharjo," Universitas Muhammadiyah Surakarta 